\title{
Open Educational Practices: a learning way beyond free access knowledge
}

Andrés Chiappe ${ }^{a}$ Silvia Irene Adame ${ }^{b}$

\section{Abstract}

Open Educational Practices (OEP) have become a growing educational trend based on Information and Communication Technologies (ICT), which have been linked both from literature and practice with emerging and complex topics such as Massive Open Online Courses (MOOC) and Open Educational Resources (OER). This essay presents a critical approach to Open Educational Practices regarding their conceptual framework and considering a current and rather than an excessive focus on free access to knowledge. We propose that transforming educational content, making it available, is not enough to produce educational innovation and consequently it becomes necessary to transform educational practices, turning them open. Although the transition from OER to OEP has already been considered in the literature, a new perspective beyond free access and costless is necessary to maximize the innovative potential of "openness".

Keywords: Open educational practices. Open educational resources. MOOC. open educational movement. Educational innovation.

\section{Introduction}

The integration of Information and Communication Technologies (ICT) has influenced educational policies and practices globally through institutional to classroom levels and is now a structural feature of most forms of formal education in 21st century (AHMAD, 2016; KANEMATSU; BARRY, 2016; MIRZAJANI et al., 2016). Such feature is very complex and includes a wide range of areas and levels of integration and manifests itself in many and various ways depending on their intention, socio-cultural context, physical conditions, infrastructure and characteristics of the people involved in the educational process (SALEHI; SHOJAEE; SATTAR, 2015).

\footnotetext{
a Universidad de La Sabana, Colombia.

b Universidad Autónoma de Guadalajara, México.
} 
One of the ways ICT's educational integration is currently being developed has to do with the resurgence of Open Education as a kind of teaching and learning that articulates two main elements: use of ICT and application of diverse attributes of "openness" such as adapting, remixing, redistributing, sharing and collaborating on spaces of free access (EBNER; SCHÖN; KUMAR, 2016; TOVAR et al., 2013). This approach represents the core of what is currently known as Open Educational Movement (CAEIRO-RODRÍGUEZ et al., 2015; LITTLEJOHN; HOOD, 2016).

From this perspective, Open Education leaves behind its origin linked to the mid-50s Distance Education and embarks itself on a path in which new elements are added over time enriching its original purpose: not only to provide access to off-campus education to students with location restrictions, time availability or personal, family or job-related reasons (HORAN, 2014), but to offer a set of customized learning experiences. It should be mentioned that in such experiences students interact in an ICT-based and flexible learning community context and an open entry (not free entry) irrespective of prior study/qualifications which was as critical for some as the flexibility it offered to students.

This new way of conceiving Open Education has generated two concrete lines of work: first, Open Educational Resources (OER); and a decade after, Open Educational Practices (OEP). Regarding the above, global agencies and programs such as UNESCO and Education For All (EFA) among others, have been promoting projects aimed at the creation, use and processing of digital educational content, and at the implementation of related free access repositories and support systems, convinced that knowledge is a common good and a driver of economic growth in developing countries (UNESCO, 2005).

Open Educational Resources are defined by Atkins et al. (2007, p. 4) as: "teaching, learning, and research resources that reside in the public domain or have been released under an intellectual property license that permits their free use or re-purposing by others." Under this definition, OER includes several types of educational resources such as course materials, modules, books, videos, tests, software, or even techniques used to support access to knowledge. It is important to note that this perspective on OER puts special focus on digital ecologies, which enables access and sharing of licensing content, mainly via the Internet. In this regard, a proper licensing facilitates use, sharing and even adaptation of educational content, without requesting permissions from the content's author (ADAME; LLORENS, 2014). 
However, despite the presented above, it must be taken into account that over the last 10 years, several definitions on OER have been published, which has generated conceptual ambiguity and confusion about this topic. In fact, one of the most recent and widely consulted OER definition by UNESCO, defined them as:

In its simplest form, the concept of Open Educational Resources (OER) describes any educational resources [...] that are openly available for use by educators and students, without an accompanying need to pay royalties or license fees (BUTCHER, 2015, p. 5).

This type of definitions locates OER almost exclusively in the field of free access, which, as we will mention later, is not considered as a factor that drives major innovations to current educational practices (OLCOTT JR, 2012). An alternative to this situation has been considered by educational community in recent years: the transit from Open Educational Resources to Open Educational Practices (INTERNATIONAL COUNCIL FOR OPEN AND DISTANCE EDUCATION, 2011; EHLERS, 2011). This alternative might be a correct way to re-route the transformative purpose of Open Educational Movement; however, it entails, once again, a conceptual problem that has been seriously affecting the practical initiatives related to OEP: such practices are commonly defined based on the use of OER. Are these more of the same?

Available literature defines Open Educational Practices as: [...] a range of practices involved in the creation, use, and management of open educational resources with the aim of improving quality and fostering innovation in education (EHLERS, 2011, p. 5), and in a similar way as:

[...] a set of activities around instructional design and implementation of events and processes intended to support learning. They also include the creation, use and repurposing of Open Educational Resources (OER) and their adaptation to the contextual setting. They are documented in a portable format and made openly available (INTERNATIONAL COUNCIL FOR OPEN AND DISTANCE EDUCATION, 2011, p. 13).

Although publications on OEP are numerous, there are not many available definitions of OEP in such specialized literature and most of them, like the presented before, are conceived as practices related to use, production, and reuse of OER. The main criticism of this way of conceiving OEP is that far from moving forward and showing other possibilities, they take a path that place themselves 
at the same point of origin of such criticism. If the call is to transit from OER to OEP because focusing exclusively on the content showed is not enough, so why to define OEP as a set of OER-related activities? There is no point on that!

A conception of OEP based only on content offers a very limited field of action to guide change or educational innovation and creates a vicious circle that narrows the transformative potential of Open Educational Movement.

Regarding the above and understanding that the "practice of education" is much more than producing and using educational content, a different understanding of Open Educational Practices is needed. In that sense, we propose OEP as a set of educational activities to which some attributes of "openness" are applied. Some of these attributes are "adaptating", "sharing", "remixing", "redistributing" or "collaborating on free access environments" (HILTON III et al., 2010). From this perspective, Open Teaching would not be "teaching with free access content" but to guide students to actively engage in activities that put learners into a position of sharing their learning, adapting products created by their peers or constructing collaboratively their knowledge with people far beyond the limits of the regular classroom. The same consideration applies to other educational practices like assessment, curriculum design, formative research, etc.

Recent research (BELL, 2016; HENRIKSEN et al., 2016; MACHADO et al., 2016; REGE COLET, 2016) shows that $21^{\text {st }}$ century educational context claims change and innovation. Recent results of standardized tests like PISA reveal structural quality issues that have been becoming evident in recent years and have triggered various educational initiatives, especially through the incorporation of ICT (SESABO et al., 2015). Examples like blended and flipped learning, $\mathrm{m}$-learning, and recently the Massive Open Online Courses (MOOC) have shown that it is possible to generate educational change if educational practices are modified going beyond setting or updating content (LEVENE; SEABURY, 2014; RAYYAN et al., 2016; STYLIANIDIS, 2015).

\section{Getting deep into free access content}

On open and distance learning, free access is mainly related to copyright's free availability to scientific, academic and cultural content located on Internet, which allows any user to read, download, copy and distribute such content according to its licensing indications. It could include printing, searching and using it without financial, legal or technical barriers, except those that are inseparable from access to the Internet itself (CHAN et al., 2002; SWAN, 2012). Free access, according 
to Wiley (2010), tends to become a common denominator in higher education, and a general working principle for Open Educational Movement.

As mentioned before, current education needs to change in the way 21 st century world needs educational models to be consistent with an uncertain and accelerated development of today's society. In that sense, the incorporation of ICT in education has been raised as one of the ways educational systems have tried to achieve educational change (DEVOLDER et al., 2010) and as part of this, the transformation of digital educational content has been considered as a viable alternative with great potential to generate positive effects in both teaching and learning (ANTONIA; ACHILLES, 2013).

For many years, several basic and advanced educational initiatives on use of open content have been taken place in many countries, mainly through Learning Objects (LO) (CAMERON; BENNETT, 2010), which have been conceived by many researchers in different ways. Colombian Ministry of Education (2012) defined LO as:

[...] a digital, self-contained, reusable set of resources with a clear learning aim that contains at least three internal changing components: content, instructional activities, and context elements. The learning object should have an external structure of information which helps its identification, storage, and recovery: the metadata (p. 30).

Several Latin American higher education institutions are facing the problem of reaching high quality educational resources to their students (RAMÍREZ MONTOYA, 2015; ROTHEN; BARREYRO, 2009). To address this situation many of these institutions have chosen to implement two different initiatives. The first has to do with the use of educational content developed by other prestigious institutions e.g., Harvard, Yale, MIT, Pennsylvania State University, Stanford, Athabasca University, University of Laval, among others. Primarily, the content used by Latin American institutions is part of what is known as open courseware and includes e-books, modules, open educational resources, e-catalogs, lessons, lectures and so on. The other initiative had to do with encouraging the production and storage of their own content, for which the creation of digital content repositories was necessary (ASTUDILLO et al., 2011). This kind of initiatives represents a crucial issue and challenge for Latin American educational institutions (HADDAD; DRAXLER, 2002), not only because of their economic, technical or administrative implications, but also due to their implications for teaching and learning. 
Duval and Ochoa (2008) report that in 2008, 39 of the most renowned Learning Object Repositories offered a range of over 400,000 learning objects, showing an increasing rate in their production and storage in specialized online repositories over the last 5 years. Regarding the above, recent research (ATENAS; HAVEMANN, 2013; DICHEV; DICHEVA, 2012; MCGREAL, 2010) shows a continuous increase of OER repositories from different universities all over the world. Those repositories bring a great opportunity of access to reliable knowledge but at the same time are poorly understood and underused by academic community by whom are seen as less useful than general web search engines, such as Google, Yahoo, etc.

We agree with Durall Gazulla et al. (2012), Mortera (2012) and Atkins et al. (2007) when they say that educational trends such as an ICT-based and progressive transformation of lifelong learning can be addressed via the enlargement of access to open content like Learning Objects.

However, despite the great transformative potential of LO associated with their open features, especially adaptation and free access, very few changes have been identified in teaching and learning because of the use of this particular type of digital educational content (KOPP; CRICHTON, 2007).

One of the reasons why Learning Objects have not really generated a deep change in educational practices has to do with the great ambiguity that arises in relation to their conceptual definition. There are many definitions available that say different things about Learning Objects (MORGADO et al., 2011), so it becomes very difficult for an educational institution or for a teacher to carry out any consistent production or use processes of this type of educational resources.

To partially overcome this situation, at early 2000s, researchers and practitioners started to refer to LO as Open Educational Resources, trying to deal with their conceptual mess achieving sufficient theoretical agreements that allow addressing them in a comprehensive and consensual manner.

Regarding this, OER appears to be the way of a renewal of Learning Objects trying to focus on adaptation as one of their main features. However, and despite this emphasis, current OER international offer seems to have ignored all this coming around again to a discourse and production of open content based on free access as the core of the whole subject (PICASSO; PHELAN, 2014).

In 2002, UNESCO coined the term "OER" to refer to educational resources with free or open access to be provided and accessed digitally through ICT with 
the purpose of being accessed, used and adapted for non-commercial purposes. In accordance with Mortera's guidelines (2012), we consider that creating open educational resources leads to a simple and powerful idea: to make access to knowledge affordable for as many people as possible.

In this regard, the Declaration of Qingdao showed a serious commitment by many Ministers of Education, high-level government officials, representatives of civil society organizations, teachers, United Nations (UN) agencies and members of academia and private sector, with rising initiatives related to Open Educational Resources. These initiatives must provide education stakeholders with opportunities to improve the quality of, and expand access to textbooks and other forms of learning content, to catalyze its innovative use and to foster knowledge creation.

On Qingdao Declaration, they committed to developing sector-wide strategies and capacity building programs to fully realize the potential of OER to expand access to lifelong learning opportunities and achieve quality education (UNESCO, 2016).

Considering the above, it is noteworthy that although free access plays an important role in the modernization of education, its main contribution is focused more towards the possibility of democratizing access to quality education (HERNANDES, 2017; WHEELER, 2010) than towards generating processes of innovation, subject that current research is still pending to demonstrate and explain.

It is well known that free access widens the possibilities of bringing many people to a diverse educational offering not only due to the elimination of costs but to time-space flexibility, which in fact, are structural features of Open Education (NAVARRETE; LUJÁN-MORA, 2015). Also, it is interesting to note that free access is perhaps the most commonly applied of the attributes of "openness" in the construction of OER, which is noticeable in the majority of OER repositories.

To ensure free access to educational content is a very good idea if we want a more democratic and inclusive education. However, overemphasizing free access finally outshines the rest of the attributes of "openness", which have more transformative potential. So, this is not about promoting a dichotomous relationship between free access and the other attributes of "openness" but to give more prominence to the last ones. Also, sharing educational content via open access, even if it is produced by highly recognized universities, is not a guarantee to receive quality education because the real value of education does not lie exclusively on its content but on effective interactions and learning experiences among teachers, students and peers. 
Open Educational Resources have enormous potential as a linking factor of digital educational content with ICT-based innovative teaching and learning practices, which becomes an interesting research space, especially when their open nature, beyond the gratuitousness, is considered. Some of these spaces are suitable for Educational Technology research, especially those that have to do with identifying the role of open content in instructional design (PIERCE, 2016), collaborative production of curriculum (ARMELLINI; NIE, 2013) and ICT-based assessment (ALGERS; LJUNG, 2015).

\section{The MOOC as another interesting OEP-related topic: are they really open or just free?}

As mentioned before, we propose a conceptualization on Open Educational Practices that differs from the conceptualizations available so far in the literature as it does not focus on open content but on openning the activities that compose such practices. Some of the educational practices that could become open are: assessment, teaching, curriculum design, educational planning, and formative research, among others. One of these practices, open teaching, is conceived as:

[...] The process of exchange of knowledge between educational stakeholders (Teacher-student and student-student) that can be performed at any time and from anywhere, using freely available tools, synchronous or asynchronously. Its open feature welcomes a third actor in the educational act: the community, the whole world (CHIAPPE; MARTINEZ, 2016, p. 25).

As a result of this practice, students can access a set of learning activities to which some of the attributes of "openness" have been applied so that finally learning occurs in an open manner. It is worth mentioning that there are available to review just a few open learning experiences that can serve as examples to demonstrate this conceptualization, except the massive open and online courses, commonly known as MOOC.

In this sense, we can say that besides the OER, Open Educational Practices have another practical manifestation that has generated in recent years a huge agitation and expectation among the academic and research community: MOOC, which are defined by McAuleyet al. (2010) as:

[...] a MOOC integrates the connectivity of social networking, the facilitation of an acknowledged expert in a field of study, and 
a collection of freely accessible online resources. Perhaps most importantly, however, a MOOC builds on the active engagement of several hundred to several thousand "students" who self-organize their participation according to learning goals, prior knowledge and skills, and common interests (p. 4).

Being a fairly complex concept because of the meaning of the four letters of their name, it is interesting to note that, like as it is currently happening with OER, the vast majority of MOOC have focused only on its component of free access as its special feature (STEWART, 2013), which is ultimately leading to their other distinctive feature: massiveness. One of the criticisms that MOOC are currently receiving just has to do with the type of learning experiences they present. Much of them have been limited to proposing only spaces of free training, when what was expected to be, besides this, is a kind of collaboration and sharing-based learning experience enriched by peer interaction with people with diverse interests, expectations and academic and cultural backgrounds. Unfortunately, most MOOC have remained as self-learning experiences based on individual video review and multiple choice tests-based assessment (GAMEEL, 2017).

However, a possible solution to providing an offer of MOOC that reflects their original spirit (known as cMOOC or connectivist MOOC) is to conceive them as spaces where open educational practices are carried out not based on the use of OER and open access but on the application of the other attributes of "openness" (RODRIGUEZ, 2013). From the perspective of Open Educational Practices conceived in this way, the most important component of the MOOC is not massiveness but openness far beyond free access which allows making things happen in a different way by addressing teaching and learning and even assessment in a context where students work in collaborative communities, learning from their peers, adapting and remixing content, sharing their learning, and providing valuable knowledge for themselves and for the communities in which they interact.

As a way to create innovative learning experiences resulting from the implementation of OEP, MOOC still have much to say. Many things in relation to key aspects of these experiences are yet to be explored and consequently there are many research opportunities. Issues that go beyond dropout rates and motivation to participate in an open course are necessary to investigate if we want to deeply understand the nature, potential and complexities of MOOC. Some of these issues have to do precisely with Open Educational Practices, such as open assessment, feedback through learning analytics, content curation and sharing, among others. So, a deeper understanding of the above, via educational technology research, 
could lead to generate better learning experiences appropriate to the demands of a networked, changing and globalized future world.

Regarding this, Castaño-Garrido et al. (2015) consider that MOOC are an evolution of networked learning and most of publications on this subject are focused on discussing their potential to provide quality education in worldwide scale rather than on measuring rigorous learning outcomes. Taking this into consideration, there are some interesting MOOC research opportunities related to identifying accreditation, teaching, assessment and curricular issues. In addition, the outstanding rates of the growth of Internet-based information represents a major challenge (VOSSEN, 2012) for Higher Education Institutions in the way of considering a more pertinent perspective based on the extensive use of digital environments.

\section{Conclusion}

The approach that has been presented so far in this article allows thinking that it is possible to create an educational change that leads the current school on a path of educational transformation and that Open Educational Practices have a highly important role in this process. Conceiving educational practices as the very essence of educational daily work, teaching strategies and learning activities can be changed to an open manner, which is a way to generate educational innovation that will positively affect the structure and the core of current educational system.

The rapid web expansion and the up growth of Internet access bring great opportunities and challenges for universities, among them, the opportunity to develop a culture of sharing, reusing and disseminating knowledge and to create more possibilities to the access to education based on extensive use of ICT. In this sense, important concepts for today's educational technology such as lifelong learning or personal learning environments can be addressed from the perspective of Open Educational Practices providing alternative exploring spaces both for researchers and educational practitioners.

Some of these spaces being ICT-supported, allow taking education beyond geographic or cultural borders as virtual or online learning experiences. Online open programs with no face-to-face interaction as the majority of MOOC, allow the participation of students and instructors in learning communities all over the world, as long as they have an Internet connection. This particular kind of educational modality offers a big opportunity to innovate educational practices making them open and taking into account not only people's cultural diversity in 
the design, delivery and evaluation of such programs, but also to take advantage of such diversity as an added value for the learning process itself.

Also, OEP will lead students to learn not in a segmented or episodic form but in a continuous, autonomous and lifelong way. In other words, educating openly allows future generations to build the skills they will need to face an uncertain future working world in which being an active participant in communities of practice, collaboration and sharing will be required; moreover, being part of an increasingly knowledge flow of today's networked society.

It was mentioned that Open Educational Practices conceived beyond the use, production and reuse of OER can be considered as a factor of educational innovation with ICT and that knowledge produced under this perspective could be preserved and mobilized through digital repositories (BARROS et al., 2015). In fact, those repositories have become a structural part of 21 st century libraries and have filled a space that was previously unthinkable for developing countries. However, low levels of expertise and digital literacy, conceptual misunderstandings and lack of creativity among those responsible for this topic in educational institutions, have led to inconvenient delays and put barriers affecting their proper development.

Nowadays, educational systems are facing major challenges in which schools and universities are called to be more open, integrative and interactive learning environments, where innovations in technology and curricula will lead to transform both teaching and learning. In that sense, institutions are meant to evolve and become learning networked communities with extensive use and adaptation of open online resources, expecting that online technologies support peer learning, social networked interactions, dialogue and exchange of knowledge.

Finally, as Open Educational Practices are still considered to be emerging within current educational context, validation spaces are needed both from research and practice to make a necessary and proper approach to this subject of study and to advance in their ontological, epistemological, practical and methodological aspects (DOMÍNGUEZ GUTIÉRREZ, 2007). Therefore, in this scenario, educational technology research must provide a wider and clearer look into the scope and limitations of Open Educational Practices as a factor of educational innovation based on ICT, far beyond free content. 


\section{Práticas Educacionais Abertas: uma maneira de aprender além do conhecimento de acesso livre}

\section{Resumo}

As Práticas Educacionais Abertas (PEA) tornaram-se uma crescente tendência educacional baseada em Tecnologias de Informação e Comunicação (TIC), que têm sido ligadas tanto da literatura quanto da prática com tópicos emergentes e complexos como os Cursos Online Maciços Abertos (MOOC) e Recursos Educacionais Abertos (REA). Este ensaio apresenta uma abordagem crítica às Práticas Educacionais Abertas em relação à sua estrutura conceitual e considerando um foco atual e não excessivo sobre o livre acesso ao conhecimento. Propomos que transformar conteúdos educacionais, disponibilizando-os não é suficiente para produzir inovação educativa e, conseqüentemente, torna-se necessário transformar as práticas educacionais, tornando-as abertas. Embora a transição da REA para a PEA já tenha sido considerada na literatura, é necessária uma nova perspectiva além do livre acesso e sem custo para maximizar o potencial inovador de "abertura".

Palavras-chave: Práticas educacionais abertas. Recursos educacionais abertos. MOOC. Movimento educativo aberto. Inovação educacional.

\section{Prácticas Educativas Abiertas: una forma de aprender más allá del conocimiento de acceso libre}

\section{Resumen}

Las Prácticas Educativas Abiertas (PEA) se han convertido en una tendencia educativa creciente basada en el uso de Tecnologías de la Información y la Comunicación (TIC), vinculada tanto desde la literatura como desde la práctica con temas emergentes y complejos como los Cursos Masivos Abiertos en Línea (MOOC) y los Recursos Educativos Abiertos (REA). Este ensayo presenta un enfoque crítico sobre las Prácticas Educativas Abiertas teniendo en cuenta su marco conceptual y su enfoque actual basado en un excesivo énfasis en el libre acceso al conocimiento. Proponemos que transformar los contenidos educativos, haciéndolos disponibles, no es suficiente para producir innovación educativa y por tanto se hace necesario transformar las prácticas educativas, volviéndolas abiertas. Aunque la transición de los REA a las PEA ya ha sido considerada en la literatura, una nueva perspectiva más allá del libre acceso y la gratuidad es necesaria para maximizar el potencial innovador de "lo abierto".

Palabras claves: Prácticas educativas abierta. Recursos educativos abiertos. MOOC. Movimiento educativo abierto. Innovación educativa. 


\section{References}

ATENAS, J.; HAVEMANN, L. Quality assurance in the open: an evaluation of OER repositories. Innoqual, v. 1, n. 2, p. 22-34, 2013.

ATKINS, D. E. et al. A review of the open educational resources (OER) movement: achievements, challenges, and new opportunities. Menlo Park: The William and Flora Hewlett Foundation, 2007.

BARROS, H. et al. Integrating educational repositories to improve the reuse of learning objects. . In: ANNUAL ACM SYMPOSIUM ON APPLIED COMPUTING, 30., 2015, Salamanca, Spain. Proceedings... New York: ACM, 2015. p. 270-2.

BELL, D. V. Twenty-first century education: transformative education for sustainability and responsible citizenship. Journal of Teacher Education for Sustainability, v. 18, n. 1, p. 48-56, 2016. https://doi.org/10.1515/jtes-2016-0004

BUTCHER, N. A basic guide to open educational resources (OER). Paris: Unesco, 2015. Available from: <http://unesdoc.unesco.org/ images/0021/002158/215804e.pdf>. Acess: 2016 Oct. 19.

CAEIRO-RODRÍGUEZ, M. et al. Supporting real open educational resources in Edu-AREA: Different views about open educational resources. In: FRONTIERS IN EDUCATION CONFERENCE, 2015, El Paso, USA. Proceedings... S. n.t.

CAMERON, T.; BENNETT, S. Learning objects in practice: the integration of reusable learning objects in primary education. British Journal of Educational Technology, v. 41, n. 6, p. 897-908, 2010. https://doi.org/10.1111/j.1467-8535.2010.01133.x

CASTAÑO-GARRIDO, C. et al. Design, motivation and performance in a Cooperative MOOC Course. Comunicar, v. 22, n. 44, p. 19-26, 2015.

CHAN, L. et al. Read the Budapest open access initiative. Budapeste: Budapest Open Access Initiative, 2002.Available from: $<$ http://www. budapestopenaccessinitiative.org/read $>$. Acess: 2016 May 27.

CHIAPPE, A.; MARTINEZ, J. . Prácticas educativas abiertas. Chía, Colombia: Universidad de La Sabana, 2016. 
COLOMBIA. Ministerio de Educación Nacional. Recursos educativos digitales abiertos: Colombia. Bogotá, 2012. (Colección Sistema Nacional de Innovación Educativa com uso de TIC). Disponível em: <http://www. colombiaaprende.edu.co/html/home/1592/articles-313597_reda.pdf $>$. Acesso em 2016 May 27.

DEVOLDER, A. et al. Identifying multiple roles of ICT coordinators. Computers and Education, v. 55, n. 4, p. 1651-5, 2010. https://doi.org/10.1016/j.compedu.2010.07.007

DICHEV, C.; DICHEVA, D. Is it time to change the OER repositories role? In: ACM/IEEE-CS JOINT CONFERENCE ON DIGITAL LIBRARIES, 12., Proceedings... ACM, 2012, Washington, D. C. p. 31-4. Available from: $<$ http://dl.acm.org/citation.cfm?id=2232826>. Acess: 2016 May 27.

DOMÍNGUEZ GUTIÉRREZ, S. El objeto de estudio en la investigación: diversas aproximaciones. Revista de Educación y Desarrollo, v. 7, n. 4, p. 41-50, 2007.

DURALL GAZULLA, E. et al. Perspectivas tecnológicas: educación superior en Iberoamérica 2012-2017. Austin: The New Media Consortium, 2012.

DUVAL, E.; OCHOA, X. Learnometrics: metrics for learning objects. Leuven: Katholieke Universiteit Leuven, 2008.

EBNER, M.; SCHÖN, S.; KUMAR, S. Guidelines for leveraging university didactics centers to support OER uptake in German-speaking Europe. Education Policy Analysis Archives, v. 24, n. 39, p. 1-13, 2016. https://doi.org/10.14507/epaa.24.1856

EHLERS, U.-D. Extending the territory: from open educational resources to open educational practices. Journal of Open, Flexible, and Distance Learning, v. 15, n. 2 , p. 1-10, 2011.

GAMEEL, B. G. Learner satisfaction with massive open online courses. American Journal of Distance Education, v. 31, n. 2, p. 98-111, Mar. 2017. https://doi.org/10.1080/08923647.2017.1300462

HADDAD, W.; DRAXLER, A., eds. Technologies for education: potentials, parameters, and prospects. Paris: Unesco, 2002.

HENRIKSEN, D. et al. Infusing creativity and technology in 21 st century education: a systemic view for change. Educational Technology \& Society, v. 19, n. 3, p. 27-37, July 2016. 
HERNANDES, P. R. A Universidade Aberta do Brasil e a democratização do ensino superior público. Ensaio: Avaliação e Políticas Públicas em Educação, v. 25, n. 95, p. 283-307, maio 2017. http://dx.doi.org/10.1590/s0104-40362017002500777

HILTON III, J. et al. The four "R"s of openness and ALMS analysis: frameworks for open educational resources. Open Learning, v. 25, n. 1, p. 37-44, 2010.

HORAN, M. No learner too far: a comparative study of the development of guidelines for distance education library services in Australia. Australian Academic and Research Libraries, v. 45, n. 1, p. 19-34, 2014. http://doi.org/10.1080/00048623.2013.870523

INTERNATIONAL COUNCIL FOR OPEN AND DISTANCE EDUCATION. Beyond OER: shifting focus to open educational practices. Oslo: Open Educational Quality Initiative, 2011. Available from: $<$ http://duepublico.uniduisburg-essen.de/servlets/DerivateServlet/Derivate-25907/OPALReport2011_ Beyond_OER.pdf $>$. Acess: 2016 Jan. 6.

KANEMATSU, H.; BARRY, D. M. ICT and the impact on education. [S. 1.]: Springer, 2015. (Intelligent Systems Reference Library, v. 91).

KOPP, G.; CRICHTON, S. Embedded or linked learning objects: implications for content development, course design and classroom use. Canadian Journal of Learning and Technology, v. 33, n. 2, p. 20-39, 2007.

LEVENE, J.; SEABURY, H. Evaluation of mobile learning: current research and implications for instructional designers. TechTrends, v. 59, n. 6, p. 46-52, 2014. https://doi.org/10.1007/s11528-015-0904-4

LITTLEJOHN, A.; HOOD, N. How educators build knowledge and expand their practice: the case of open education resources. British Journal of Educational Technology, v. 48, n. 2, p. 499-510, Mar. 2017. https://doi.org/10.1111/bjet.12438

MACHADO, M. S. P. et al.. Educational innovation and digital competencies: the case of OER in a private Venezuelan university. International Journal of Educational Technology in Higher Education, v. 13, n. 1, p. 1, 2016. https://doi.org/10.1186/s41239-016-0006-1

MCAULEY, A. et al. In the open: the MOOC model for digital practice. Charlottetown, Canada: University of Prince Edward Island, 2010. 
MCGREAL, R. Open educational resource repositories: an analysis. In: ANNUAL FORUM ON E-LEARNING EXCELLENCE, 3., 2010, Dubai. Proceedings... Available from: $<$ http://elexforum.hbmeu.ac.ae/Proceeding/ PDF/Open\%20Educational\%20Resource.pdf>. Acess: 2016 May 27.

MIRZAJANI, H. et al. Teachers' acceptance of ICT and its integration in the classroom. Quality Assurance in Education, v. 24, n. 1, p. 26-40, 2016. https://doi.org/10.1108/QAE-06-2014-0025

MORGADO, E. M. M. et al. Promoting quality during learning-object management through experts and users. International Journal of Technology Enhanced Learning, v. 3, n. 2, p. 190-203, 2011. https://doi.org/10.1504/IJTEL.2011.039402

MORTERA, F. Participación del Tecnológico de Monterrey en el Proyecto Recursos educativos abiertos y móviles para la formación de investigadores educativos. In: RAMIREZ, M. S.; BURGOS, V. (Eds.). Recursos educativos abiertos y móviles para la formación de investigadores: investigaciones y experiencias prácticas. México: Lulú Editorial Digital, 2012. p. 30-31.

NAVARRETE, R.; LUJÁN-MORA, S. OER-based learning and people with disabilities. . In: 2015 INTERNATIONAL CONFERENCE ON INTERACTIVE COLLABORATIVE AND BLENDED LEARNING - ICBL 2015, México Cityy. Proceedings... [S.n.t]

OLCOTT JR, D. OER perspectives: emerging issues for universities. Distance Education, v. 33, n. 2, p. 283-90, 2012. https://doi.org/10.1080/01587919.2012.700561

ORGANIZACIÓN DE LAS NACIONES UNIDAS PARA LA EDUCACIÓN, LA CIENCIA Y LA CULTURA - UNESCO. Educación para todos: el imperativo de la calidad. Paris: Unesco, 2005. (Informe de seguimiento de La EPT em el Mundo). Available from: <http://unesdoc.unesco.org/ images/0015/001501/150169s.pdf>. Acess: 2016 May 27.

PICASSO, V.; PHELAN, L. The evolution of open access to research and data in Australian higher education. International Journal of Educational Technology in Higher Education, v. 11, n. 3, p. 122-33, 2014.

PIERCE, M. Looking at OER with a critical eye: strengthening OER initiatives by focusing on student learning. Community \& Junior College Libraries, v. 22, n. 1-2, p. 11-7, Jul. 2016. https://doi.org/10.1080/02763915.2016.1205391 
RAMÍREZ MONTOYA, M. S. Acceso abierto y su repercusión en la sociedad del conocimiento: reflexiones de casos prácticos en Latinoamérica. Education in the Knowledge Society, v. 16, n. 1, p. 103-18, 2015. https://doi.org/10.14201/eks2015161103118

RAYYAN, S. et al. A MOOC based on blended pedagogy. Journal of Computer Assisted Leiarning, v. 32, n. 13, p. 190-201, 2016. https://doi.org/10.1111/jcal.12126

REGE COLET, N. M. From content-centred to learning-centred approaches: shifting educational paradigm in higher education. Journal of Educational Administration and History, v. 49, n. 1, p. 75-86, Nov. 2016. https://doi.org/10.1080/00220620.2017.1252737

RODRIGUEZ, O. The concept of openness behind $\mathrm{c}$ and $\mathrm{x}-\mathrm{MOOCs}$ (Massive Open Online Courses). Open Praxis, v. 5, n. 1, p. 67-73, 2013. https://doi.org/10.5944/openpraxis.5.1.42

ROTHEN, J. C.; BARREYRO, G. B. Avaliação, agências e especialistas: padrões oficiais de qualidade da educação superior. Ensaio: Avaliação e Politicas Públicas em Educação, v. 17, n. 65, p. 729-52, 20 out. 2009. https://ddoi.org/10.1590/S0104-40362009000400010

SALEHI, H.; SHOJAEE, M.; SATTAR, S. Using e-learning and ICT courses in educational environment: a review. English Language Teaching, v. 8, n. 1, p. 63-70, 2015. https://doi.org/10.5539/elt.v8n1p63

SESABO, J. K. et al. Opportunities and challenges in implementing distance learning and e-learning: a case study. In: KEENGAWE, J. Handbook of research on educational technology integration and active learning. Hershey: IGI Global, 2015. p. 329-345.

STEWART, B. Massiveness + openness $=$ new literacies of participation? Journal of Online Learning and Teaching, v. 9, n. 2, p. 228, 2013.

STYLIANIDIS, P. Mobile learning: open topics, concept and design of a learning framework. In: 2015 INTERNLATIONAL CONFERENCE ON INTERACTIVE MOBILE COMMUNICATION TECHNOLOGIES AND LEARNING - IMCL 2015, Thessaloniki, Greece. . Proceedings... Available from: $<$ http://ieeexplore.iee.org/document/7359634/>. Acess: 2016 May 27.

SWAN, A. Policy guidelines for the development and promotion of open access. Paris: UNESCO, 2012. 
TOVAR, E. et al. Impact of open educational resources in higher education institutions in spain and latin americas through social network analysis. In: ASEE ANNUAL CONFERENCE AND EXPOSITION, 2013, Atlanta, Georgia. Proceedings... Available from: < https://peer.asee.org/19700>. Acess: 2016 May 27.

UNITED NATIONS EDUCATIONAL, SCIENTIFIC AND CULTURAL ORGANIZATION - UNESCO. The Qingdao declaration.Paris: Unesco, 2016. Available from: $<$ http://www.unesco.org/new/en/education/resources/infocus-articles/qingdao-declaration>. Acess: 2016 May 27.

VOSSEN, P. H. The challenge of information balance in the age of affluent communication. In: STROTHER, J. B.; ULIJN, J. M.; FAZAL, Z. (Eds.). Information overload. Hoboken: John Wiley \& Sons, 2012. p. 41-59.

WHEELER, S. Open content, open learning 2.0: using wikis and blogs in higher education. In: EHLERS, U.-D.; SCHNECKENBERG, D. (Eds.). Changing cultures in higher education. Berlin: Springer, 2010. p. 103-14.

WILEY, D. Openness as catalyst for an educational reformation. Educause Review, v. 45, n. 4, p. 15-20, 2010.

\section{Information of authors:}

Andrés Chiappe: Doctor in Educational Sciences. Center of Technologies for Academia, Universidad de La Sabana, Colombia. Professor in Doctorate in Education and Master in Educational Technology. Contato: andres.chiappe@unisabana.edu.co

Silvia Irene Adame: Doctor in Sciences oriented to Technology. Department of Distance Education, Universidad Autónoma de Guadalajara, México. Professor in post-degree in Quality Management Systems for Innovation and Master in Engineering in Information and Communication Technologies. Contato: sadame@edu.uag.mx 